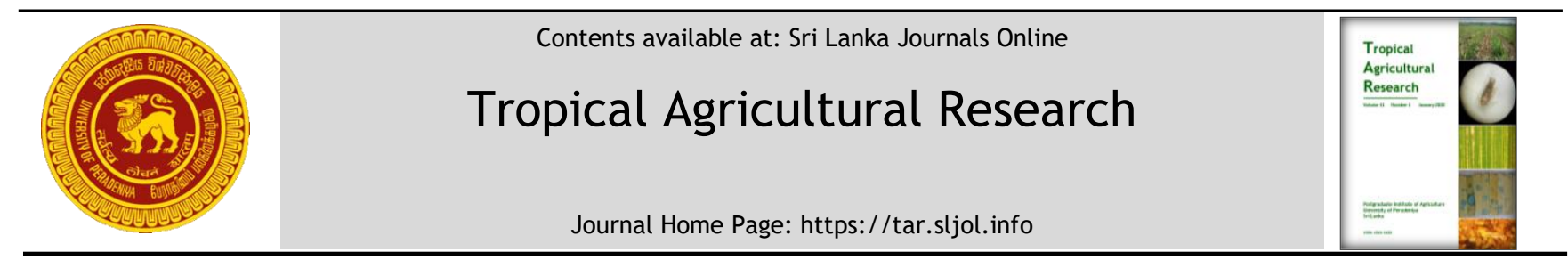

\title{
Equilibrium Relations in the Coconut Sector: An Analysis of Fresh Nut, Oil and Desiccated Coconut Market in Sri Lanka for the Period
}

\section{6-2017}

\author{
M.G.D. Abeysekara ${ }^{1 *}$, D.V.P. Prasada ${ }^{2}$ and P.M.E.K. Pathiraja ${ }^{1}$ \\ ${ }^{1}$ Postgraduate Institute of Agriculture, University of Peradeniya, Peradeniya, Sri Lanka \\ ${ }^{2}$ Department of Agricultural Economics and Business Management, Faculty of Agriculture, University of Peradeniya, \\ Peradeniya, Sri Lanka
}

\section{ARTICLE INFO}

\section{Article history:}

Received: 12 July 2019

Accepted: 23 October 2019

Available online: 1 December 2019

\section{Keywords:}

Coconut

Elasticity

Partial equilibrium model

Seemingly unrelated regression

\section{Citation:}

Abeysekara, M.G.D., Prasada, D.V.P. and Pathiraja, P.M.E.K. (2020). Equilibrium Relations in the Coconut Sector: An Analysis of Fresh Nut, Oil and Desiccated Coconut Market in Sri Lanka for the Period 1956-2017. Tropical Agricultural Research, 31(1): 01-12.

DOI: http://doi.org/10.4038/tar.v31i1.8339

Abeysekara, M.G.D.

https://orcid.org/0000-0002-1777-565X

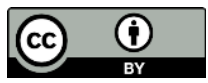

\begin{abstract}
The objective of this paper is to assess the equilibrium relations in the fresh nut, oil and Desiccated Coconut (DC) market in Sri Lanka with special emphasis on determining the supply and demand elasticities. To achieve this objective, the Partial Equilibrium Model (PEM) previously adopted for the Sri Lankan coconut industry was reestimated using Seemingly Unrelated Regression (SUR) method. Annual data on prices, quantities and other supply and demand related data for the period 1956-2017 were used for the analysis. The PEM captures the linkages in both production and consumption between the three markets. The results revealed that estimations are consistent with previous studies except for the income variable in demand equations for both fresh and oil markets where only the latter is statistically significant with negative coefficient indicating that oil has become an inferior good. Both the own price elasticity of supply and demand of fresh nut and oil were statistically significant with comparatively lower magnitudes whereas it was significant and higher in the DC market. When compared with the previous studies, the findings of the present study revealed that the magnitudes of the supply and demand elasticities in all three coconut markets have changed over the past decade and implications of those changes are further observed in the changes of directions of supply and demand relationships. Therefore, the coconut market model may also be extended further by incorporating other important sub-sectors as well.
\end{abstract}

*Corresponding author : abeysekaradilini@gmail.com 


\section{INTRODUCTION}

Coconut (Cocos nucifera L.), one of the four major plantation crops in Sri Lanka, is intimately connected with the Sri Lankan culture, food consumption and the economy. The industry contributes about 0.7 percent to the Gross Domestic Products (GDP) and 3.3 percent to the total export earnings (Central bank of Sri Lanka, 2017). The coconut market consists of different products including fresh coconut, kernel products (i.e., coconut oil, desiccated coconut, coconut milk, coconut cream etc.), and other various by-products (i.e., coconut fibre, coconut shell charcoal, activated carbon etc.). Of these, fresh nuts and coconut oil are primarily directed to the domestic market, while the destination of the DC is the export market. These products account for 70 percent, 3 percent, and 15 percent of the total coconut production in the country, respectively.

The contemporary picture of the domestic coconut sector is different to that of plantation era in the early 1970 s, where the contribution of the coconut sector to the GDP was around 5 percent and the exportable surplus was almost half of the total coconut production (Pathiraja et al., 2015). Simultaneously, the area cultivated in the estate sector (i.e. $>20 \mathrm{ac}$ ) under coconut has eroded from 25 percent in 1982 to 16 percent in 2014, while the smallholder sector has risen from 75 percent to 84 percent during the same period (Department of Census and Statistics, 2014). This has mainly been caused by, amongst the other reasons, fragmentation of lands that took place during the past few years extensively in the coconut triangle where 67 percent of the coconut lands are concentrated. Since early 1980s', the domestic coconut production has been stagnating while the domestic use of culinary nuts has been increased by nearly one third from 1,200 to 1,800 million nuts owing to the increasing population. Since the domestic consumption is the primary objective that must be attended, at present the nuts directed to industrial processing (exportable surplus) has reduced to 30 percent which was recorded as 50 percent during the 1970s'.

Furthermore, processing sector has diversified from the traditional coconut export products, desiccated coconut (DC) and coconut oil towards the other value-added products such as virgin coconut oil, coconut milk, coconut milk powder etc. Hence, the pattern of fresh nut utilisation has changed over the years as shown in Figure 1. Even though DC market maintains a static export volume, the share of export volume of coconut oil has diminished gradually over the recent past due to the opening of the edible oil market and the competition between oil producers and the high-valued other kernel producers to allocate raw materials for their industries.

The role of fresh coconuts, coconut oil and other coconut-based products in diet is one of the most important advantages of the domestic coconut sector forming a stable market for the producers. However, during the last two decades the food consumption patterns observed in Sri Lanka have been changing gradually and it is common for the consumption of coconut and related products as shown in Table 1. Forces responsible for shaping demand are varied. On one hand, along with the trade liberalisation of the domestic edible oil market in the early $80 \mathrm{~s}$, tariff concessions were granted and thereby the importers were permitted to import different edible oils in large quantities. Thus the availability of substitute oils in the local market at relatively cheap prices has increased. On the other hand, not only the economic and demographic factors but also changes in lifestyles, which influence consumers' tastes and preferences were observed. 


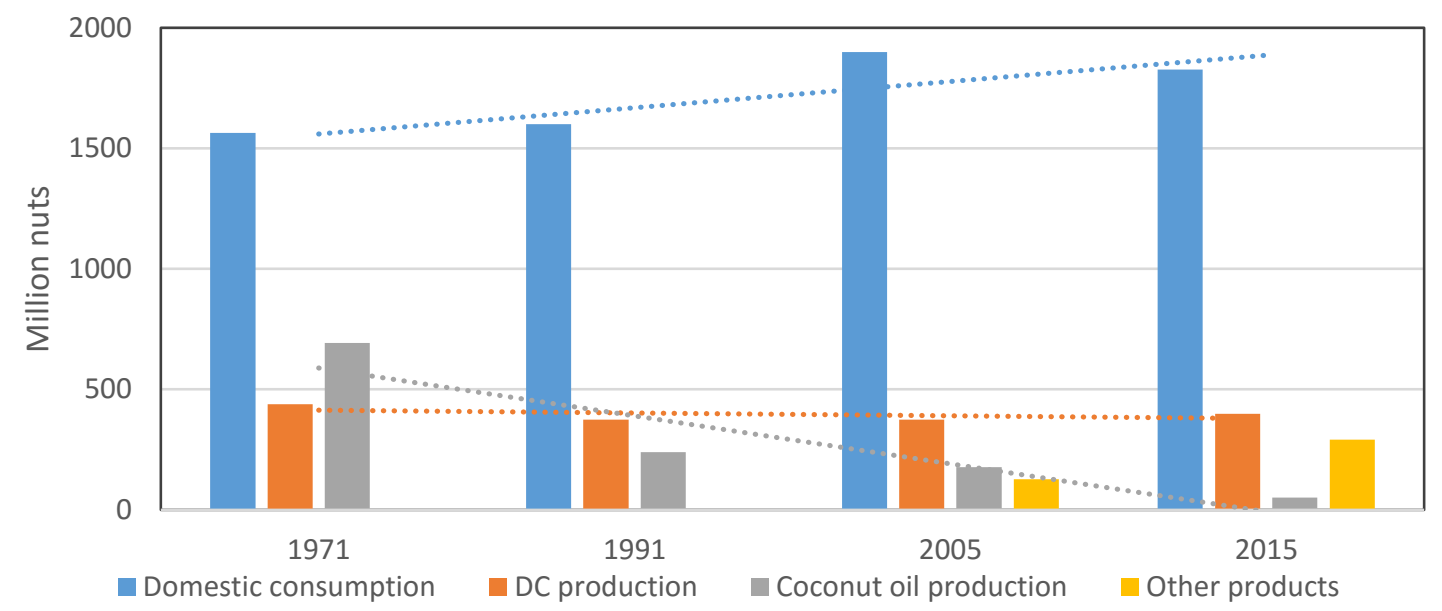

Figure 1: Changes in Pattern of nut utilization in the coconut sector 1971-2015

Note: "Other" category includes virgin coconut oil, coconut milk and milk powder, etc. Source: Authors' calculations based on CDA annual reports

Table 1: Per capita monthly consumption of fresh coconut, coconut oil and edible oils

\begin{tabular}{lccc}
\hline Survey Period & Fresh nuts (number) & Coconut oil (ml) & Other edible oils (mL) \\
\hline $2006 / 2007$ & 7.41 & 349.47 & 20.23 \\
$2009 / 2010$ & 7.37 & 361.56 & 27.08 \\
$2012 / 2013$ & 7.29 & 361.22 & 28.97 \\
2016 & 7.18 & 378.08 & 44.89 \\
\hline
\end{tabular}

Source: Household Income and Expenditure Survey reports of the Department of Census and Statistics (various years)

\section{Problem statement}

Coconut is still of considerable economic importance, which generates employment opportunities, foreign exchange and an essential food item for domestic consumption. Hence, both input and output market of the coconut sector subjected to frequent government policy interventions. The degree to which individuals, consumers or producers change their demand or the amount supplied in response to such interventions can be measured by supply and demand elasticity (Hennebery \& Tweeten, 1991). Understanding the characteristics and magnitude of elasticity is essential to assess the policy efficacy. Amongst the different approaches researchers have used to achieve similar objectives in the coconut sector, the commonly used approaches were analysing the producers (the supply side of the market) (Dumayas, 1983; Gunawardana, 1988; Karunakaran and Gangadharan, 2014), analysing the consumers (the demand side of the market) (Samarajeewa and Gunathilake, 1999) or considering both as a system (Recto-Librero, 1971; Silva, 1979; Samarajeewa, et al., 2002) to determine the equilibrium relationships in the market.

Fresh coconut is being the fundamental raw material in the coconut industry, the fresh coconut market is closely linked either directly or indirectly with other related markets in both production and consumption. Hence, modelling the coconut industry as a system is of obvious importance for ascertaining the equilibrium relationships for formulating and analysing economic policies. The study is timely as it is evident that the Sri Lankan coconut sector has confronted with several challenges as discussed earlier leaving uncertainty on the direction it forwards thus changing the equilibrium relationships in the sector. However, after 2002 there is no comprehensive study has been conducted to econometrically assess equilibrium relationships in the coconut sector. Therefore, it is important to revisit the coconut market equilibrium to ascertain the supply and demand directions of the domestic coconut market. 


\section{Objectives of the study}

In this process of assessing the equilibrium relations in the coconut market, the study aims to update the partial equilibrium model developed by Samarajeewa (2002). The specific objectives of the study were to estimate the supply and demand elasticities in the; i) fresh nut market with other related variables, ii) first derived market (coconut oil) in the presence of cross price, iii) second derived market (DC) in the presence of export price and to compare the estimated elasticity values with the previously estimated figures to determine the supply and demand directions in the domestic coconut market.

\section{METHODOLOGY}

The coconut market equilibrium model used for this study comprises of three interrelated markets; i) fresh coconuts, ii) coconut oil and, iii) desiccated coconut (DC) and they have modelled in terms of behavioural functions, which describe the key features of production and consumption patterns. Fresh coconut is the primary product in the system and it links with the other two markets as the fresh coconut is the primary raw material for the other two products.

\section{Theoretical model}

In the view of above features, the coconut market model for Sri Lanka is developed as follows. Supply of coconut products is a function of its own price and other exogenous variables and it can be given as;

$$
Q_{i t}^{S}=f\left(P_{i t}^{f}, Z_{i t}^{S}\right)
$$

Where; $Q_{i}^{S}=$ the total quantity supplied of the coconut product at time $t$

$$
\begin{gathered}
P_{i}^{f}=\text { the producer price of the product } \\
\text { i at time t } \\
Z_{i t}^{S=} \text { the vector of other determinants } \\
\text { of supply (i.e., price of inputs, } \\
\text { technological change) }
\end{gathered}
$$

Coconut product demand is a function of its own price, income and other demand shifters as depicted below.

$$
Q_{i t}^{d}=f\left(P_{i t}^{r}, I_{t}, Z_{i t}^{S}\right)
$$

Where; $Q_{i}^{d}=$ the total quantity demanded of the coconut product at time $\mathrm{t}$

$P_{i}^{r}=$ retail price of the product $\mathrm{i}$ at time $\mathrm{t}$

$I_{t}=$ per capita consumer income at time $\mathrm{t}$

$Z_{i t}^{S}=$ the vector of other determinants of demand (i.e., taste and preferences, price of substitutes)

The producer price in the supply function and the consumer price in the demand function are appropriately linked at the market equilibrium and it is given by;

$$
P_{i t}^{f}=f\left(P_{i}^{r}\right)
$$

The three coconut product markets are linked by production at the equilibrium of the fresh coconut market and it is depicted by the following identity. Production of other coconut kernel products including coconut milk and coconut milk powder were not considered here as the production of these products started rising after 2005, which represent a smaller portion of the considered time duration in the study. However, these are included in the "other" category in the model closure of the fresh nut market.

$$
Q_{t 1}^{s}=Q_{t 1}^{d}+Q_{t 2}^{s}+Q_{t 3}^{S}
$$

Where; $Q_{t 1}^{S}=$ total quantity supplied in the fresh coconut market at time $t$

$Q_{t 1}^{d}=$ quantity of fresh coconut demand at time $t$

$Q_{t 2}^{S}=$ quantity of coconut oil production in fresh nut equivalent $Q_{t 3}^{S}=$ the quantity of DC production in fresh nut equivalent

\section{Empirical model}

The partial equilibrium models are comprehensive market models as they analyse in detail both sides of the equation between supply and demand of specific agricultural sub-sectors, including the price formation and interdependency of agricultural inputs and outputs between different product lines. A typical agricultural policy model under partial equilibrium framework consists of following subcomponents including i) production/supply 
equation, ii) demand equation, iii) price linkage equation and iv) model closure.

Since coconut is a perennial crop and hence the production decision are not made during the current year, the producer's response to changes in an economic variable is not spontaneous. Therefore, the length of lag in production response is a function of the characteristics of the industry, which may change over time due to market structure and production technology changes (Samarajeewa, 2002). Moreover, according to the past studies, the responsiveness of coconuts to inputs like fertilizer ranges between 3-5 years (Silva, 1972) and 1-2 year lag of rainfall influences the fresh nut production (Child, 1974; Peries and Peries, 1993). These characters were considered in the fresh nut market. In the DC market, all most all the production is oriented for the export market and the domestic consumption is negligible. However, the export destinations of DC has changed over the decades. As a specific group of consumers cannot be selected to explain the consumer behaviour of DC exports, export demand function for DC was specified as a function of border price. The Colombo F.O.B price was considered as the world price. In several occasions the Colombo F.O.B price was considered as the world market price. According to the annual reports of Asian Pacific Coconut Community, use of F.O.B Colombo price is justifiable. Considering those facts, the supply and demand equations for the coconut market was derived as shown in Table 2.

Table 2: Summary of equations used to model the coconut market

\begin{tabular}{|c|c|c|}
\hline Market & Equation & \\
\hline $\begin{array}{l}\text { Fresh nut market } \\
\text { Supply Equation } \\
\text { Demand Equation } \\
\text { Price linkage } \\
\text { Market clearing } \\
\text { Identity }\end{array}$ & $\begin{array}{l}Q S_{1}=\beta_{0}+\beta_{1} \cdot P P_{t-k}-\beta_{2} \cdot P F_{t-2}+\beta_{3} \cdot R F_{t-1}+\beta_{4} \cdot C S_{t-k}+\beta_{5} \cdot \text { Time } \\
Q D_{1}=\beta_{6}+\beta_{7} \cdot R P_{t}+\beta_{8} \cdot I C+\beta_{9} \cdot \text { Time } \\
P W P_{t}=\beta_{10}+\beta_{11} \cdot R P_{t} \\
Q S_{1}=\left(Q D_{1} * \text { Population }\right)+c f 1 \cdot Q S_{2}+c f 2 \cdot Q S_{3}+\text { Other }\end{array}$ & $\begin{array}{l}(5) \\
(6) \\
(7) \\
(8)\end{array}$ \\
\hline $\begin{array}{l}\text { Coconut oil marke } \\
\text { Supply Equation } \\
\text { Demand Equation } \\
\text { Price linkage } \\
\text { Veg. Oil Price } \\
\text { Market clearing } \\
\text { Identity }\end{array}$ & $\begin{array}{l}Q S_{2}=\beta_{12}+\beta_{13} \cdot \text { PPcno }_{t}-\beta_{14} \cdot P P_{t}+\beta_{15} \cdot \text { Time } \\
Q D_{2}=\beta_{16}-\beta_{17} \text { RPcno }_{t}-\beta_{18} I C+\beta_{19} \text { RPpko }_{t}+\beta_{20} \text { RPso }_{t} \\
\text { PPcno }_{t}=\beta_{21}+\beta_{22} \cdot \text { RPcno }_{t} \\
\text { RPpko }_{t}=\text { WPpko }_{t}\left(1+\text { Tariff }_{t}\right) \\
Q S_{2}=Q D_{2}+\text { Year end stocks } 1\end{array}$ & $\begin{array}{l}(9) \\
(10) \\
(11) \\
(12) \\
(13)\end{array}$ \\
\hline $\begin{array}{l}\text { DC market } \\
\text { Supply Equation } \\
\text { Demand Equation } \\
\text { Price linkage } \\
\text { Market clearing } \\
\text { Identity }\end{array}$ & $\begin{array}{l}Q S_{3}=\beta_{23}+\beta_{24} \cdot P P d c_{t}-\beta_{25} \cdot P P_{t}+\beta_{26} \cdot \text { Time } \\
E D_{3}=\beta_{27}-\beta_{28} \cdot F O B d c_{t}+\beta_{29} \cdot \text { Time } \\
P P d c_{t}=F O B d c_{t}(1-\text { tax })-\text { other } \\
Q S_{3}=Q E D_{2}+\text { Year end stocks } 2\end{array}$ & $\begin{array}{l}(14) \\
(15) \\
(16) \\
(17)\end{array}$ \\
\hline $\begin{array}{l}\text { Note: } Q S_{1}=\text { Total coconut } \\
\text { of coconuts at time } t, Q D_{2}= \\
\text { coconut at time } t-k, R P_{t}=R e \\
=\text { Producer price of } D C \text { at } t i \\
\text { time } t-1, C S_{t-k}=\text { Cultivation } \\
\text { at time } t, \text { Residuals }{ }^{*}=\text { All } \\
\text { coconut oil), cf } 2=\text { Conversi } \\
\text { price of Palm kernel oil, } R I \\
\text { price of palm kernel oil at } t\end{array}$ & 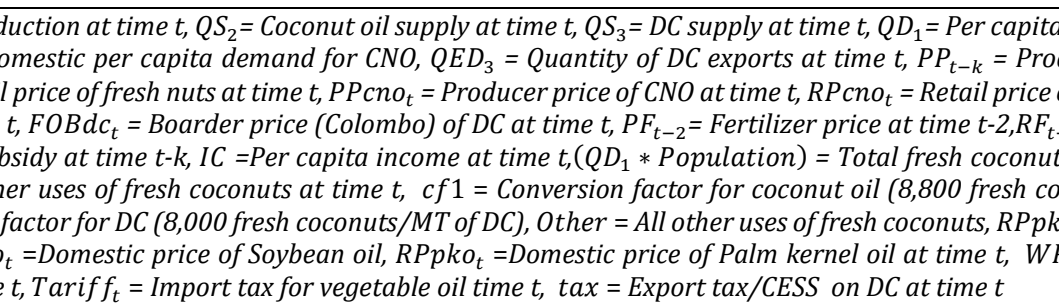 & $\begin{array}{l}\text { nsumption } \\
\text { cer price of } \\
\text { CNO, PPdc } \\
\text { Rainfall at } \\
\text { nsumption } \\
\text { nuts/MT of } \\
=\text { Domestic } \\
o_{t}=\text { World }\end{array}$ \\
\hline
\end{tabular}

\section{Data and data sources}

Annual data for the period of 1956 to 2017 were used for the analysis. Data on total coconut production, coconut oil production,
DC production and exports, rainfall figures, and the producer prices for fresh nuts, coconut oil and border prices of DC were taken from the 'Coconut Statistics' published annually by 
the Coconut Development Authority, (CDA) Sri Lanka. The retail prices for fresh nuts and coconut oil were taken from the Statistical Abstract published by the Department of Census and Statistics, Sri Lanka for the required time period. The coconut fertilizer prices were taken from the publications by the National Fertilizer Secretariat. The per capita consumption of fresh nut and coconut oil was estimated by dividing the total annual consumption figures by the population figures. The domestic supply of coconut oil was calculated by subtracting exports and the addition of imports to total oil production wherever applicable. The domestic consumption of DC is negligible and therefore not specified in the model.

Among the many subsidies given in the coconut sector, only the cultivation subsidy was considered and the monetary value of subsidy payments was extracted from CDA reports. The export tax figures for DC and import tariff rate for palm oil were taken from the government gazette notifications. The domestic retail price for palm kernel oil and soy oil was not available. Therefore, the C.I.F (cost, insurance, freight) price for palm kernel oil and soy oil obtained from the Department of Customs was used as an approximation to the domestic price. Figures on domestic population, per capita income and price indices were obtained from the Annual Reports of the Central Bank of Sri Lanka. All the price and income values used in the study were deflated using Consumer Price Index.

\section{RESULTS AND DISCUSSION}

The coconut market was modelled in terms of nine structural equations and four identities that describe the characteristics of the three sub-sectors. Initially, every single equation was estimated using Ordinary Least Square method. Different forms of equations were tested. However, the linear-linear model was found as to better fit for all the equations than the other forms and hence linear model was selected as the appropriate model to be used in the system equations as well. With a focus on achieving results consistent with the economic theory while representing the characteristic nature of the coconut market and, different variables with various lag lengths were tested and fitted. Descriptive statistics of the data used for the estimation are presented in Table 3.

Table 3: Descriptive statistics of the data

\begin{tabular}{|c|c|c|c|c|c|}
\hline \multicolumn{2}{|c|}{ Market } & Variable & Unit & Mean & Std. Dev. \\
\hline \multirow{8}{*}{ Fresh Nuts } & \multirow[t]{5}{*}{ Supply } & Total coconut Production & Million nuts & $2,529.35$ & 312.35 \\
\hline & & Producer Price & Rs/nut & 20.06 & 8.63 \\
\hline & & Fertilizer Price & $\mathrm{Rs} / \mathrm{kg}$ & 30.18 & 8.09 \\
\hline & & Rainfall & $\mathrm{mm}$ & $1,938.78$ & 282.26 \\
\hline & & Cultivation Subsidy & Rs/Mn. & 279.43 & 219.60 \\
\hline & \multirow[t]{3}{*}{ Demand } & Per capita nut consumption & Nuts & 114.96 & 9.98 \\
\hline & & Retail Price of a nut & Rs/nut & 26.07 & 10.64 \\
\hline & & Per capita income & Rs & $154,456.30$ & $113,504.60$ \\
\hline \multirow{5}{*}{$\begin{array}{l}\text { Coconut oil } \\
\text { (CNO) }\end{array}$} & \multirow[t]{3}{*}{ Supply } & Total coconut oil supply & $\mathrm{Mt}$ & $63,848.42$ & $32,935.06$ \\
\hline & & Producer price & Rs/kg & 182.64 & 60.16 \\
\hline & & Producer price of fresh nuts & Rs/nut & 20.06 & 8.63 \\
\hline & \multirow[t]{2}{*}{ Demand } & Per capita consumption & $\mathrm{kg}$ & 2.75 & 1.13 \\
\hline & & Retail price of coconut oil & $\mathrm{Rs} / \mathrm{kg}$ & 233.29 & 71.79 \\
\hline \multirow{5}{*}{$\begin{array}{l}\text { Desiccated } \\
\text { Coconut } \\
\text { (DC) }\end{array}$} & \multirow[t]{3}{*}{ Supply } & Desiccated coconut supply & Mt & $46,484.29$ & $12,323.29$ \\
\hline & & Producer price & $\mathrm{Rs} / \mathrm{kg}$ & 197.00 & 67.83 \\
\hline & & Producer price of fresh nuts & Rs/nut & 20.06 & 8.63 \\
\hline & \multirow[t]{2}{*}{ Demand } & Exports & Mt & $45,333.65$ & $11,917.48$ \\
\hline & & FOB price & $\mathrm{Rs} / \mathrm{kg}$ & 238.73 & 110.60 \\
\hline
\end{tabular}


The system of equations was estimated using Seemingly Unrelated Regression (SUR) method and the estimated coefficients are presented in Table 4. The results generated from the econometric estimations were consistent with the economic theory.

Table 4: Results of the econometric estimation of the coconut market using SUR model

\begin{tabular}{|c|c|c|c|c|}
\hline Market & $\begin{array}{l}\text { Dependent } \\
\text { variable }\end{array}$ & Independent variable & Estimate by SUR & P-value \\
\hline \multirow{7}{*}{$\begin{array}{l}\text { Fresh } \\
\text { coconut }\end{array}$} & \multirow{4}{*}{$\begin{array}{l}\text { Coconut } \\
\text { supply }\end{array}$} & Producer price & $5.3390 *$ & 0.10 \\
\hline & & Fertilizer price & -0.1160 & 0.96 \\
\hline & & Cultivation subsidy & $0.2950^{* *}$ & 0.02 \\
\hline & & Technology & $13.6700^{* *}$ & 0.00 \\
\hline & \multirow{2}{*}{$\begin{array}{l}\text { Coconut } \\
\text { demand }\end{array}$} & Retail price & $-0.4230^{*}$ & 0.06 \\
\hline & & $\begin{array}{l}\text { Per capita income } \\
\text { Taste and Preferences }\end{array}$ & $\begin{array}{l}-0.0110 \\
-0.1880\end{array}$ & $\begin{array}{l}0.53 \\
0.16\end{array}$ \\
\hline & Producer & Retail price & $0.6600^{* *}$ & 0.00 \\
\hline \multirow{7}{*}{$\begin{array}{l}\text { Coconut } \\
\text { oil }\end{array}$} & \multirow{3}{*}{$\begin{array}{l}\text { Coconut oil } \\
\text { supply }\end{array}$} & Producer price & $92.6500^{* *}$ & 0.06 \\
\hline & & Fresh coconut price & $-787.5700^{* *}$ & 0.05 \\
\hline & & Time & $-1,511.7000^{* *}$ & 0.00 \\
\hline & \multirow{3}{*}{$\begin{array}{l}\text { Coconut oil } \\
\text { demand }\end{array}$} & Retail price & 0.0017 & 0.20 \\
\hline & & Per capita Income & $-0.0030^{* *}$ & 0.00 \\
\hline & & Domestic price of palm oil & $0.0240^{* *}$ & 0.01 \\
\hline & Producer & Retail price & $0.7847^{* *}$ & 0.00 \\
\hline \multirow[t]{5}{*}{ DC } & \multirow[t]{3}{*}{ DC supply } & Producer price & $29.5700 * *$ & 0.02 \\
\hline & & Fresh nut price & $-730.3100^{* *}$ & 0.00 \\
\hline & & Time & $328.6300^{* *}$ & 0.01 \\
\hline & \multirow{2}{*}{$\begin{array}{l}\text { DC export } \\
\text { demand }\end{array}$} & F.O.B (Colombo) price & -13.5200 & 0.17 \\
\hline & & Time & 66.2900 & 0.56 \\
\hline
\end{tabular}

Econometric estimation of the fresh nut market

The fresh coconut market was specified in terms of supply equation, demand equation and price linkage. The two-year lag producer price was found to be positive and significantly influence the producer's decision on coconut production. The lag length of coconut cultivation subsidy influencing the coconut supply was found to have significantly contributed to the coconut supply with a lag length of 13 years. A coconut palm usually comes into bearing within 6-8 years after planting (Silva, 1979) however without much attention of the grower a palm comes into the bearing with available resources depending on the favourable environmental factors (Silva, 1972). Hence, the contribution of cultivation subsidy to the coconut supply with 13-year lag is realistic under these specific conditions. The fertilizer price was negatively related and it was not significant. Notably, 25 percent of the coconut growers apply fertilizer as an input in their coconut lands and among them, the majority are coconut estate holders ( $>20$ acres) hence fertilizer price is not a significant variable. The trend variable, which was included as a proxy for evaluating the technological and management changes on coconut production, has a positive impact on coconut production. The demand for fresh nuts was negatively and significantly related to the retail price of fresh nuts. However, the income is negatively related to the fresh nut demand which is not significant and it contradicted with the economic theory. 


\section{Econometric estimation of the coconut oil market}

The coconut oil market was modelled using supply, demand equations and price linkage. In the estimated coconut oil supply function, coconut oil is positively and significantly related with one year lagged own price and negatively and significantly related with fresh coconut price which is used as the input price. Here, instead of copra, which is the raw material of making coconut oil the fresh nut was considered avoiding the intermediate step to maintain the consistency in the direct linkages among the three products concerned in the study. The trend variable shows a significant negative trend of coconut oil supply over time. Along with the liberalization of the edible oil market, coconut oil becomes less competitive in the domestic edible oil market with the other cheaper substitute vegetable oils. Consequently, coconut oil loses its importance as a major export product. The coconut oil demand was negatively and significantly relate to per capita income. However, the retail price is not significantly contributed to the coconut oil demand. The domestic price of palm oil which was incorporated as a close substitute to the coconut oil shows a positive and significant relationship with the coconut oil demand.

\section{Econometric estimation of the DC market}

Supply function and an export demand equation was specified and estimated for the DC market. DC supply was positively and negatively related to producer price and the input price (i.e. fresh nut price) respectively. Both these relationships are significant at 5 percent significant level. The volume of export demand was negatively related to F.O.B. Colombo price.

\section{Estimation of elasticities}

Using the parameters estimated in the SUR model, the elasticity values with respect to prices and income were calculated to understand the directions of supply and demand relationships for the three coconut markets considered in the study. For the comparison purpose of these elasticity estimates with the previous studies, they are presented in Table 5 and Figure 2.

Table 5: Comparison of estimated elasticity values for the coconut markets

\begin{tabular}{|c|c|c|c|c|c|}
\hline \multirow[b]{2}{*}{ Market } & \multirow[b]{2}{*}{ Equation } & \multirow[b]{2}{*}{ Variable } & \multicolumn{3}{|c|}{ Estimated Elasticity values } \\
\hline & & & $\begin{array}{l}\text { Present } \\
\text { study }^{1}\end{array}$ & $\begin{array}{l}\text { Samarajeewa } \\
(2002)^{2}\end{array}$ & $\begin{array}{c}\text { Jayalath and } \\
\text { Weerahewa } \\
(2014)^{3}\end{array}$ \\
\hline \multirow[t]{4}{*}{ Fresh nuts } & Supply & Producer price & $0.118^{*}$ & $0.195^{* *}$ & \\
\hline & & Fertilizer price & -0.004 & -0.079 & \\
\hline & Demand & Retail price & $-0.050^{*}$ & $-0.110^{* *}$ & \\
\hline & & Per capita income & -0.125 & $0.300^{* *}$ & \\
\hline \multirow{6}{*}{$\begin{array}{l}\text { Coconut } \\
\text { Oil }\end{array}$} & Supply & Producer price & $0.128^{* *}$ & $0.512^{* *}$ & 0.01 \\
\hline & & Fresh coconut price & $-0.186^{* *}$ & $-0.362^{* *}$ & $-0.19 * *$ \\
\hline & Demand & Retail price & -0.226 & $-0.479 * *$ & $-0.19 * *$ \\
\hline & & Per capita income & $-0.337^{* *}$ & -0.054 & 0.01 \\
\hline & & Price of palm oil & $0.168^{* *}$ & 0.510 & $0.25^{* *}$ \\
\hline & & Price of soy oil & 0.038 & 0.079 & \\
\hline \multirow[t]{3}{*}{ DC } & Supply & DC producer price & $0.114^{* *}$ & 0.048 & \\
\hline & & Fresh coconut price & $-0.678^{* *}$ & $-0.220^{* *}$ & \\
\hline & $\begin{array}{l}\text { Export } \\
\text { Demand }\end{array}$ & DC price at the border & -0.077 & -0.041 & \\
\hline $\begin{array}{l}\text { te: } 1 \text { Present s } \\
\text { 2. Samaraj } \\
\text { 3. Jayalath }\end{array}$ & dy-Annual data 1 & $\begin{array}{l}2017 \\
\text { ta } 1956-2000 \\
- \text { Monthly data 1990-2009 }\end{array}$ & & & \\
\hline
\end{tabular}


According to the estimates, the responsiveness of fresh nut producers to own price is 0.12 which is an inelastic value. This estimate is consistent with the inelastic shortrun supply elasticity values obtained for coconut and other perennial crops including tea, 0.03 (Akiyama \& Trivedi, 1987) and 0.097 (Weerahewa et al., 1997) and, rubber, 0.14

Fresh Nut Market

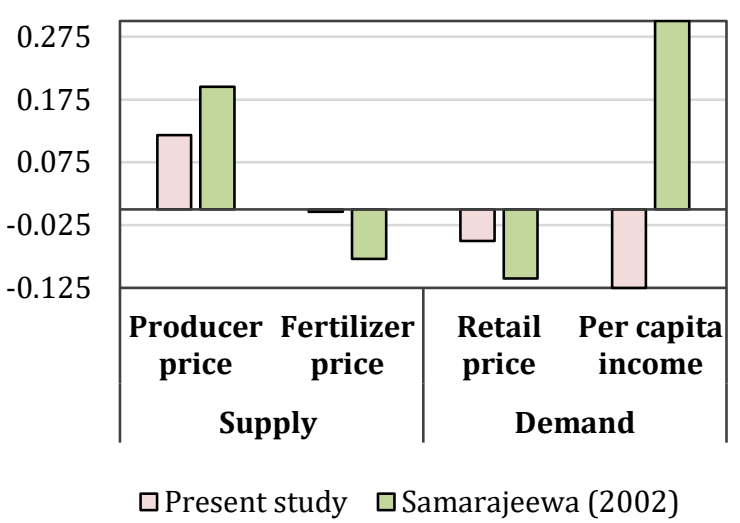

(Samarappuli and Bogahawatta,1993),0.1 (Kumar and Sharma,2006), 0.04 (Soontaranurak and Dawson, 2015; Mustafa et $a l, 2016)$. However, the magnitude of the estimate exhibits a marginal drop from that of the previous study by Smarajeewa (2002) referring to a reduction in responsiveness of fresh nut producers to change in price.

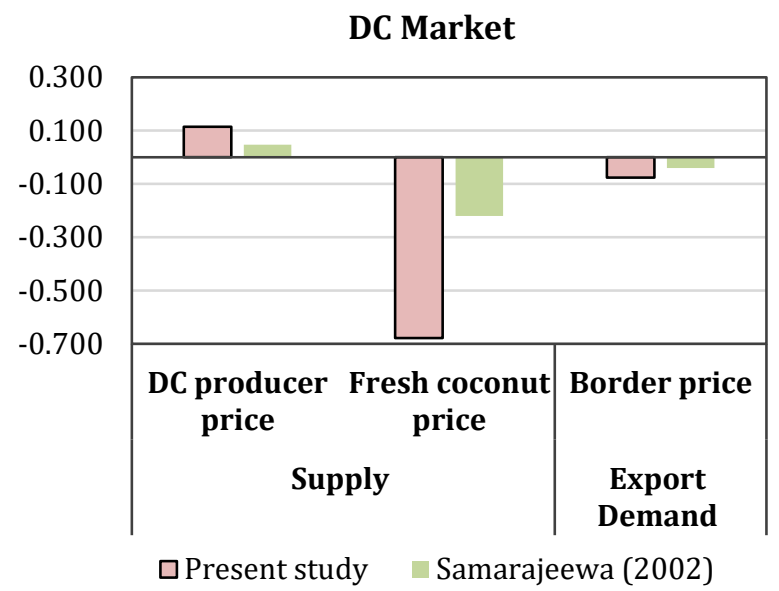

\section{Coconut Oil Market}

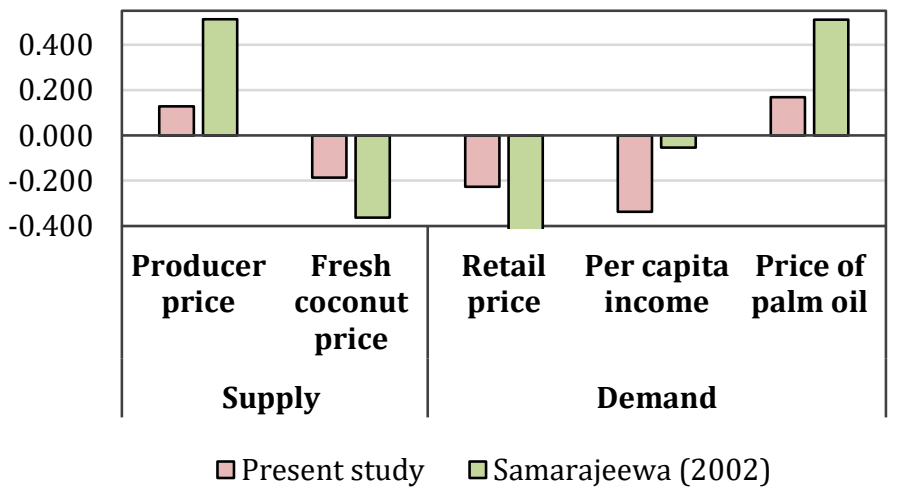

Figure 2: Comparison of estimated elasticity values in previous studies for the three markets

The supply elasticity of coconut oil with respect to its own price is 0.128 which is lower than that of the estimate of Samarajeewa in 2002 indicating that the responsiveness of coconut oil producers to change in producer price have considerably reduced over the time. Meantime, the supply elasticity of coconut oil with respect to the fresh coconut price which was considered as the raw material also exhibits the same trend. However, this estimate is consistent with the most recent estimate by Jayalath and
Weerahewa (2014). During the recent past exports of coconut oil have been insignificant and at present, virtually all coconut oil produced in Sri Lanka consumes locally. Furthermore, the domestic coconut oil industry is characterized by a large number of small to medium scale and a few numbers of large scale oil millers, and obsolete machinery and technologies they could not compete with the emerging high tech industries like coconut cream and milk powder for raw material. 
In contrast, the own-price elasticity of DC supply has increased up to 0.114 from 0.05 implying that the DC market maintains its competitiveness with other emerging kernel processing industries. However, the responsiveness of the supply elasticity in the DC market with respect to the fresh nut price has decreased up to -0.678 implying that for a one percent increase in coconut price, the DC supply decreases by 0.678 percent.

The demand elasticity with respect to own price in both fresh nut and oil market has eroded by comparing to the values in the previous study in 2002 while the DC market has moved into opposite direction.Still the demand elasticity of oil is in the same range as the study in 2014. The estimated income elasticities in both fresh nut and oil market have negative signs wherein the latter it was statistically significant. This indicates that these goods have become inferior goods for consumers. This trend is also evident in the aggregate level in terms of quantity consumed of coconut. Moreover, consumption of other edible oils has increased tremendously leaving the increase of coconut oil consumption insignificant.

\section{CONCLUSION}

Given the significant transformations of the coconut sector in terms of both demand and supply-side factors, this study revisits the equilibrium relationships in the coconut market to update the partial equilibrium model adopted by Samarajeewa (2002). The present study considers the time period from 1956-2017 and hence has sufficient data to incorporate the external foreign market pressure where the previous studies were unable to capture. The estimated parameters in the system equations are consistence except for the income variable in fresh nut and oil demand equations where only the latter one is significant. This suggests that coconut oil has become an inferior good. If the sample can be aggregated for different income groups, the inferiority of coconut oil for higher-income groups may emerge.

The magnitude of the fresh nut supply elasticity in the short run with respect to own price has marginally reduced whereas the coconut oil supply elasticity has reduced substantially compared to the previous studies. In contrast, DC industry remains competitive recording an increase in the magnitude of the own-price elasticity value.

The demand elasticity with respect to retail price in both raw and oil market has reduced. The income elasticity in the raw market which was significant in the previous study does not significantly contribute to the fresh nut demand according the present study. However, income elasticity in the oil market has moved to an opposite direction along with a considerable change in the magnitude.

The findings of the present study revealed that the equilibrium relationships in the coconut market have changed over the past decade and implications of those changes are further observed by the changes in the directions of supply and demand relationships. Therefore, the coconut market model may also be extended further by incorporating other important sub-sectors as well. Furthermore, it is recommended to be emphasized in the above equilibrium relationships in formulating policies to regulate coconut and related markets.

\section{ACKNOWLEDGEMENTS}

Guidance given by Chairman, Coconut Research Board, Director, Coconut Research Institute and the support given by Head and staff of the Agricultural Economics and Agribusiness Management Division at Coconut Research Institute for the success of this study are appreciated. 


\section{REFERENCES}

Akiyama, T. \& Trivedi, P. K., (1987). Vintage Production Function Approach to Perennial Crop Supply: An Application to Tea in Major Producing Countries. Journal of Econometrics, Volume 36, pp. 133-161.

Asian Pacific Coconut Community, (2016). Coconut Statistical Year Book, Jakarta.

Central bank of Sri Lanka, (2017). Annual Report, Colombo: Central Bank of Sri Lanka.

Child, R. (1974). Coconuts: Tropical Agricultural Series. 2 ed. London: Longman Group Ltd..

Coconut Development Authority, (19702017). Coconut Statistics, Colombo: Coconut Development Authority.

Department of Census and Statistics, (2014). Economic Census 2013/2014 - agricultural Activities, Colombo: Department of Census and Statistics.

Dumayas, E. E., (1983). A Supply Response Study of Coconut in the Philippines, Manhattan, Kansas: Kensas State University.

Gunawardana, P. J., (1988). Production Response to prices in the Coconut Industry of Papua New Guinea: A Comment on the Methodology and A Re-Estimation. CORD, 4(01), pp. 74-84.

Hennebery, S. R. \& Tweeten, L. G., (1991). A Review of International Agricultral Supply Response. Journal of International Food and Agribusiness Marketing, 2(3), pp. 49-68.

Jayalath, K. V. N. N. \& Weerahewa, J., (2014). Tariff Endogeneity: Effects of Export Price of Desiccated Coconuts on Edible Oil Market in Sri Lanka. Tropical Agricultural Research, 25(4), pp. 376-386.

Karunakaran, N. \& Gangadharan, K., (2014). Supply Response of Coconut Cultivation in Kerala. Economic Affairs, 59(4), pp. 681-686.

Kumar, P. \& Sharma, A., (2006). Perennial Crop Supoply Response Functions: The Case of
Indian Rubber, Tea and Coffee. Indian journal of Agricultural Economics, 61(4), pp. 630-646.

Mustafa, G., Latif, I. A. \& Egwuma, H., (2016). An Emprical Analysis of Supply Response of Rubber in Malaysia. American Journal of Agricultural and Biological Sciences, 12(4), pp. 148-156.

Pathiraja, E., Griffith, G., Farquharson, R. \& Faggin, R., (2017). Specifying and Testing an Equilibrium Displacement Model of the Coconut MArket in Sri Lanka. Australian Agribusiness Review, Volume 25, pp. 55-86.

Pathiraja, E., Griffith, G., Farquharson, R. \& Faggian, R., (2015). The Sri Lankan Coconut Industry: Current Status and Future Prospects in a Changing Climate. Australasian Agribusiness Perspectives - paper 106, pp. 123.

Peries, T. S. G. \& Peries, R. R. A., (1993). Effect of Bimonthly Rainfall on Coconut Yield in the Low Country Intermidiate Zone (IL1) of Sri Lanka. Journal of the Coconut Research Institute in Sri Lanka, pp. 1-11.

Recto-Librero, A., (1971). An Economic Model for Analyzing Demand for Philippine Coconut Products. The Philippines Statistician, 20(1), pp. 1-19.

Samarajeewa, S. \& Gunathilake, H. M., (1999). Estimation of Demand Function for Coconut Oil: A Cointegration Analysis. Tropical Agricultural Reserach, Volume 11, pp. 324334.

Samarajeewa, S. R., (2002). The Economic Impact of Selcted Government Interventions on the Coconut Sector of Sri Lanka, Unpublished.

Samarajeewa, S., Weerahewa, J. \& Gunathilake, H. M., (2002). Tariff Policy Liberalization of Edible Oil Market and Its implications on the Coconut Producers in Sri Lanka. Tropical Agricultural Research, Volume 14, pp. 317326.

Samarappuli, I. N. \& Bogahawatta, C., (1993). An Econometric Study of the World Rubber 
Economy. Tropical Agricultural Research, Volume 5, pp. 142-157.

Silva, M. A. T. D., (1972). Fertlizer Experiments and Coconut Yield. Ceylon Coconut Planters' Review, Volume 7, pp. 92-94.

Silva, S. D., (1979). The Coconut Industry in Sri Lanka: An Analysis of Government intervention Measures, Canbera: Australian National University.

Soontaranurak, K. \& Dawson, P. J., (2015). Rubber Acreage Supply Response in Thailand:
A Cointegration Appraoch. The Journal of Developing Areas, 49(2), pp. 23-37.

Trivedi, P. K., (1986). A Framework for Studying the Supply response of Perennial Crops, s.l.: Economic Analysis and Projections Department, World bank.

Weerahewa, J., Goddard, E. \& Perera, G. M. S., (1997). Impact of Research on Tea Production in Sri Lanka. Tropical Agricultural Research, Volume 9, pp. 96-107. 